\title{
Developing Security Community in the Western Balkans: The Role of the EU and NATO
}

Paper prepared for the EUSA Tenth Biennial International Conference

May 17-19, 2007, Montréal, QC, Canada

Panel 1J: CSFP Case Studies

\author{
Suzette Grillot \\ Associate Professor \\ Department of Political Science and School of \\ International and Area Studies (SIAS) \\ The University of Oklahoma \\ Tel: (405) 325-6003 \\ Fax: (405) 325-7402 \\ Email:sgrillot@ou.edu \\ Valerie J. D'Erman \\ Graduate Research Assistant \\ Department of Political Science \\ University of Oklahoma \\ Hester Hall 166, 729 Elm St. \\ Norman, OK 73072 \\ Phone: (405) 325-1584 \\ Fax: (405) 325-7402 \\ Email: vjderman@ou.edu \\ Rebecca J. Cruise \\ Graduate Research Assistant \\ Department of Political Science \\ University of Oklahoma \\ Phone: (405) 325-1584 \\ Fax: (405) 325-7402 \\ Email: rebeccajcruise@ou.edu
}




\title{
Developing Security Community in the Western Balkans: The Role of the EU and NATO
}

\begin{abstract}
This paper examines how external third-parties, such as international organizations, can play a role in facilitating the development of security community and international integration within post-conflict societies. The formation of a security community includes the emergence of trust, belongingness, and reconciliation, along with internalizing the notion of resolving conflicts in a peaceful manner. This paper studies the roles of the EU and NATO in potentially fostering a regional security community in the Western Balkans. Both organizations have become heavily involved and invested in the region attempting to extend to the area the well established security community that exists among Europe and its Trans-Atlantic partners, while all the countries of the Western Balkan region have expressed a desire to join European institutions and become a part of the Euro-Atlantic community. But what are the implications of external encouragement of security community? The socialization of individual countries, rather than the region as a whole, contributes more to each country's self-perception as a member state rather than as a part of a regional community. This study offers unique insight into how and why feelings of trust and a sense of community can be encouraged by external actors - and how and why trust and community can filter down to the most local level within post-conflict societies. Such insight will further interests in enhancing conflict resolution and post-conflict reconstruction.
\end{abstract}




\section{Introduction}

The six countries of the Western Balkans (Albania, Bosnia \& Herzegovina [BiH], Croatia, Macedonia, Serbia and Montenegro $)^{1}$ have commanded significant international attention over the past decade. This troubled area has experienced much violent conflict in recent years and continues to suffer from tension and instability today. The Western Balkan region will soon be entirely surrounded by EU and NATO members, yet most will remain on the outskirts of the Western community for the foreseeable future. These countries, after all, are hard cases for European integration. In addition to engaging in recent violent conflict and exhibiting lesser developed political and economic systems, these countries continue to experience ethnic tensions, border disputes, immigration and refugee concerns, poor infrastructures, a diffusion of weaponry, and significant problems associated with organized crime and corruption. Moreover, one of these countries was a target of Western military action (Serbia) and two countries remain under international protection (BiH and the Kosovo region of Serbia).

Despite and because of these facts, Western countries and international organizations (IOs) have become heavily involved and invested in the region attempting to extend to the area the well established security community that exists among Europe and its Trans-Atlantic partners. $^{2}$ All the countries of the Western Balkan region have expressed a desire to join European institutions and become a part of the Euro-Atlantic community. Euro-Atlantic

\footnotetext{
${ }^{1}$ This is in accordance with EU parlance, which refers to these same six countries (those formerly a part of Yugoslavia, minus Slovenia and plus Albania) as the "Western Balkans" within the context of South-East Europe. See the Communication from the Commission to the Council and the European Parliament entitled "The Western Balkans and European Integration,” available at http://europa.eu.int/eurlex/lex/LexUriServ/site/en/com/2003/com2003 0285en01.pdf, or EurActiv.com on the enlargement policy section at http://www.euractiv.com/en/enlargement/eu-western-balkans-relations/article-129607.

${ }^{2}$ The concept of security community, which will be discussed below, refers to the development of trust, shared values, and peaceful resolution of conflict among states that interact regularly, come to identify with one another, and consider violent interaction to be unthinkable. See Emanuel Adler and Michael Barnett, eds., Security Communities (Cambridge: Cambridge University Press, 1998).
} 
institutions such as the EU and $\mathrm{NATO}^{3}$ are regularly engaging the Western Balkans region and socializing the countries to develop a local sense of community. We are particularly interested in how the EU and NATO, external third parties, facilitate a sense of trust and belonging - a sense of community - within and among the countries of the Western Balkan region. Therefore, this paper seeks to address the following questions:

- What specifically have the EU and NATO encouraged regarding community building?

- How can and do such organizations work to enhance the development of security community?

- What are the implications of external encouragement of security community?

- Will such external efforts result in a local sense of trust and belonging?

Most studies of the Balkan region focus largely on conflict and disintegration rather than cooperation and integration. ${ }^{4}$ Moreover, most studies of security community focus extensively and entirely on the development and implications of community between countries, but none

\footnotetext{
${ }^{3}$ While this paper deliberately focuses on these two organizations, they are not the only ones at work in the region. The choice of the EU and NATO is due to our focus on the external encouragement of community in the Western Balkan region. Other important IOs operating in the region - the Organization of Security Cooperation in Europe (OSCE) and United Nations (UN) - include the Western Balkan countries as members, whereas these countries are not members of the EU and NATO, two organization that have play a role in developing a sense of community within and among these non-member countries. For more on the role of the OSCE as a security community building institution, see Emanuel Adler, "Seeds of Peaceful Change: The OSCE's Security Community-Building Model," in Adler and Barnett, eds., Security Communities, pp. 119-160. Adler also refers to how OSCE security community initiatives have diffused to other European institutions, such as the EU and NATO. See pp. 143-147.

${ }^{4}$ See John Phillips, Macedonia: Warlords and Rebels in the Balkans (New Haven: Yale University Press, 2004); Stipe Mesic, The Demise of Yugoslavia (Budapest: CEU Press, 2004); Paulin Kola, The Myth of Greater Albania (New York: New York University Press, 2003); Norman M. Naimark and Holly Case, eds., Yugoslavia and Its Historians: Understanding the Balkan Wars of the 1990s (Stanford: Stanford University Press, 2003); Cvijeto Job, Yugoslavia's Ruin: The Bloody Lessons of Nationalism, A Patriot's Warning (Lanham: Rowman \& Littlefield Publishers, 2002); V.P. Gagnon, Jr. The Myth of Ethnic War: Serbia and Croatia in the 1990s (Ithaca: Cornell University Press, 2004); Carole Rogel, The Breakup of Yugoslavia and Its Aftermath (Westport, CT: Greenwood Press, 2004); Sebrina P. Ramet, Balkan Babel: The Disintegration of Yugoslavia from the Death of Tito to the Fall of Milosevic, $4^{\text {th }}$ edition (Boulder: Westview Press, 2002); Tom Gallagher, The Balkans after the Cold War: From Tyranny to Tragedy (New York: Routlege, 2003); Raju G.C. Thomas, eds., Yugoslavia Unraveled: Sovereignty, Self-Determination, Intervention (Lanham: Lexington Books, 2003); Mark Almond, Europe's Backyard War: The War in the Balkans (London: Heinemann, 1994); Ian Oliver, War and Peace in the Balkans: The Diplomacy of Conflict in the Former Yugoslavia (London: IB Tauris, 2005); and Joel M. Halpern and David A. Kideckel, eds., Neighbors at War: Anthropological Perspectives on Yugoslav Ethnicity, Culture and History (Pennsylvania State University, 2000).
} 
address the problematic nature of post-civil-conflict societies where many security concerns emanate not from external threats but internal ones. Studies of security community also do not focus on the ways in which a security community is created and/or encouraged by IOs. This study, therefore, offers several practical and theoretical implications. Theoretically, the study contributes to the growing body of international relations literature that addresses both material and non-material causes of security cooperation. It will also broaden the study of security community to help us understand the ways in which such community can develop with the help of IOs in post-civil-conflict societies. Practically, the findings will allow us to highlight the sociological consequences of international involvement in the Western Balkan region in an effort to develop best practices for IO engagement in post-conflict areas.

What follows is an overview of the concept of security community, an synopsis of the role that IOs can play, an outline of the theoretical expectations specific to the Western Balkan region which includes the research hypothesis and expected behavior for this paper, a short discussion of the history of violent conflict in the Western Balkan region, an assessment of international interaction with the region in an effort to develop a sense of security community in the Western Balkans, and a conclusion that highlights our findings and suggests the direction for future research.

\section{The Evolution of Security Community}

Concerning communities at the international level, scholars have suggested that groups of states form a "society" when they are aware of common interests and values, and shared interpretations of reality. They consider themselves to be bounded by the same sets of rules in their relations with each other, and share the same affinity for common institutional practices. 
The states that comprise an "international society" or "community" interact in such a way that they unilaterally and unconsciously consider each other, their common values and sets of rules as factors before selecting a course of action. ${ }^{5}$

Such "communities" at the international level have helped scholars understand how and why states come to cooperate on matters of security. As in other communities, members of a "security community" share a common identification. More specifically, however, they expect that they can solve common social problems together without resorting to violent or aggressive behavior. ${ }^{6}$ "A security community, therefore, is one in which there is real assurance that the members of that community will not fight each other physically, but will settle their disputes in some other way."

Political scientists have often employed the psychological and social- psychological concepts of identity when studying political behavior. Over five decades ago, Harold Lasswell and Abraham Kaplan suggested that "identification serves as the mechanism for the creation of the political 'we.' It is the 'we' which lies at the center of political phenomena.” 8 Political identity has helped scholars understand and explain behavior among and between political groups such as soldiers and officers; armies and civilians; ethnicities and nations.

\footnotetext{
${ }^{5}$ Hedley Bull, The Anarchical Society: A Study of Order in World Politics (New York: Columbia University Press, 1977), pp. 13-14; Hedley Bull, "The Importance of Grotius in the Study of International Relations," in Hedley Bull, Benedict Kingsbury, and Adam Roberts, eds., Hugo Grotius and International Relations (Oxford: Clarendon Press, 1990), p. 72; and Onuf, World of Our Making, p. 106. These types of "societies" or "communities" among states have also been called "moral communities," and distinguished from "secular communities." See Thomas Franck, The Power of Legitimacy Among Nations (New York: Oxford University Press, 1990), especially p. 51.

${ }^{6}$ Karl Deutsch, et. al., Political Community and the North Atlantic Area (Princeton: Princeton University Press, 1957), p. 5.

${ }^{7}$ Ibid.

${ }^{8}$ Harold D. Lasswell and Abraham Kaplan, Power and Society: A Framework for Political Inquiry (New Haven: Yale University Press, 1950), p. 12.
} 
A political identity, defined as "a shared perspective on the self as a participant in politics,” is viewed by many to be a major determinant of political actions. ${ }^{9}$ It helps us understand how and why individuals behave as they do, as well as how and why collectivities behave, in the political realm. Identification helps explain the dynamics of nation-building with the coming together of many individuals because of a common perception of a national identity; and it helps explain the collective actions of one nation as together it seeks to protect and enhance its identity. ${ }^{10}$ Moreover, identification allows us to explore the possibility of “transnational identities" that will affect political processes on a global scale. ${ }^{11}$ In other words, identity fosters our exploration, understanding and explanation of political cooperation and international integration.

Most scholars who study the concept of security community tend to focus on what Karl Deutsch calls pluralistic security community (PSC). ${ }^{12}$ Members of a PSC operate based on “mutual responsiveness.” Their shared identity, sense of sympathy, loyalty and "we-feeling” allow PSC members to predict each others behavior, and cooperate accordingly. ${ }^{13}$ Moreover, PSC members "frame problems and solutions according to shared values and redefine security as a community, rather than a state or interstate problem.”14 Such conditions make violent behavior among and between PSC members much less likely as together they seek the peaceful resolution of security problems. Adler and Barnett highlight how "Deutsch observed a pluralistic security community whenever states become integrated to the point that they have a sense of community,

\footnotetext{
${ }^{9}$ Harold D. Lasswell, "Future Systems of Identity in the World Community,” in Cyril E. Black and Richard A. Falk, eds., The Future of the International Legal Order Volume IV (Princeton: Princeton University Press, 1972), pp. 331. Quote from p. 4.

${ }^{10}$ William Bloom, Personal Identity, National Identity and International Relations (Cambridge: Cambridge University Press, 1990).

${ }^{11}$ Lasswell, "Future Systems of Identity in the World Community," pp. 9-26.

${ }^{12}$ Ibid.

${ }^{13}$ Emanuel Adler, “Europe’s New Security Order: A Pluralistic Security Community,” in Beverly Crawford, ed., The Future of European Security (Berkeley: University of California Press, 1992), pp. 291-92.

${ }^{14}$ Ibid., pp. 294-95.
} 
which, in turn, creates the assurance that they will settle their differences short of war. In short, Deutsch claimed that those states that dwell in a security community had created not simply a stable order but, in fact, a stable peace.”15

The notion of interaction is of extreme importance to the understanding of PSCs and the subsequent behavior of their members. Karl Deutsch emphasized, for example, "communication" and "transaction flows" among states as the keys to community building and peaceful relations. Positive interaction, he argued, creates the "we-feeling" and the "sense of community." ${ }^{16}$ Scholars such as Emanuel Adler have expounded on Deutsch's focus on interstate communications and transactions to highlight the "learning" processes involved in the creation, maintenance and enhancement of PSCs. Specifically, Adler suggests that PSC members must learn and be socialized into the "we" of a community. He argues that this involves:

the adoption by policymakers of new interpretations of reality, as they are created and introduced to the political system by individuals and institutions. This implies that national policymakers are subject to absorbing new meanings and interpretations of reality, as generated in intellectual, bureaucratic, and political circles, and therefore are subject to changing their interests and ability and/or willingness to consider new courses of action. Seen in this light, learning increases the capacity and motivation to understand competing alternatives to a currently entertained inference and becomes a creative process by which alternatives and preferences or "interests" are generated. The capacity to generate new cognitions is related not only to the acquisition of new information about

\footnotetext{
${ }^{15}$ Adler and Barnett, “Security Communities in Theoretical Perspective,” p. 3. Also see Adler, "Europe’s New Security Order,” pp. 291-92; Emanual Adler and Michael Barnett, "Governing Anarchy: A Research Agenda for the Study of Security Communities,” Ethics and International Affairs, Vol. 10 (1996), pp. 67-68; Alexander Wendt, "Anarchy is What States Make of It," International Organization, Vol. 46 (Spring 1992), pp. 395-421; and Wendt, "Collective Identity Formation and the International State."

${ }^{16}$ Karl W. Deutsch, "Communication Theory and Political Integration,” in Philip E. Jacob and James V. Toscano, eds., The Integration of Political Communities (Philadelphia: J.B. Lippincott Company, 1964), pp. 46-74; especially p. 54. Also on the importance of communication and transaction flows see Claudio Cioffi-Revilla, Richard L. Merritt and Dina A. Zinnes, eds., Communication and Interaction in Global Politics (Beverly Hills: Sage Publications, Inc., 1987). On the negative consequences of communication and transactions (e.g., nationalism), see K.J. Holsti, “Change in the International System: Interdependence, Integration, and Fragmentation," in Ole R. Holsti, Randolph M. Siverson and Alexander L. George, eds., Change in the International System (Boulder: Westview Press, 1980).
} 
the environment but also to new and innovative ways of drawing linkages between causes and effects and between means and ends. ${ }^{17}$

The learning and socialization process implies that PSC members transmit to each other, as well as to prospective members, their values, beliefs and expectations. Through such processes, identities come to be shared, cooperation emerges, and PSCs prosper. ${ }^{18}$

\section{International Organizations}

Of particular relevance in the Western Balkans regarding the development of security community are the EU and NATO. Very few studies of security community explore the role of organizations in fostering a sense of community. Instead, studies often treat international organizations as the result of state activities to develop such communities. In other words, IOs are most likely seen as the effect (dependent variable) rather than the cause (independent variable) of security community. ${ }^{19}$

Theoretically, IOs can enhance the development of a security community through the process of socialization. In addition to the more rationalist and materialist explanations for EU

\footnotetext{
${ }^{17}$ Emanuel Adler, "Cognitive Evolution: A Dynamic Approach for the Study of International Relations and Their Progress," in Adler and Crawford, eds., Progress in Postwar International Relations, p. 52. For more on learning and foreign policy decisions, see Jack Levy, "Learning and Foreign Policy: Sweeping a Conceptual Minefield," International Organization, Vol. 48 (Spring 1994), pp. 279-312; and Janice Gross-Stein, "Political Learning by Doing: Gorbachev as Uncommitted Thinker and Motivated Learner,” International Organization, Vol. 48 (Spring 1994), pp. 155-83. For more on socialization, see John Ikenberry and Chalres Kupchan, "Socialization and Hegemonic Power,” International Organization, Vol. 44 (Summer 1990), pp. 283-315; and Richard Dawson, Kenneth Prewitt, and Karen S. Dawson, Political Socialization: An Analytical Study, Second Edition (Boston: Little, Brown and Company, 1977).

${ }^{18}$ Adler, “Cognitive Evolution,” p. 58.

${ }^{19}$ For important exceptions see Emanuel Adler, "Seeds of Peaceful Change: The OSCE's Security CommunityBuilding Model," in Adler and Barnet, eds., Security Communities, pp. 119-160; and Emilian R. Kavalski, "The International Socialization of the Balkans,” The Review of International Affairs, Vol. 2 (2003), pp. 71-88. Other studies focus specifically on international organizations as agents of socialization and teachers of norms. See Andreas Hasenclever, Peter Mayer, and Volker Rittberger, Theories of International Regimes (Cambridge: Cambridge University Press, 1997); Richard M. Price and Mark W. Zacher, The United Nations and Global Security (New York: Palgrave Macmillan, 2004); Martha Finnemore, "International Organizations as Teachers of Norms: The United Nations Educational, Scientific and Cultural Organization and Science Policy,” International Organization, Vol. 47, No. 4 (1993), pp. 565-97; and Martha Finnemore, Defining National Interests in International Society (Ithaca, NY: Cornell University Press, 1996).
} 
and NATO expansion, ${ }^{20}$ a more recent body of literature concentrates on socialization theories within international relations. Socialization is a key concept of social constructivism, whereby the social relations between actors mutually construct identities and the ideas that prescribe and proscribe behavior. ${ }^{21}$ International institutions become social institutions around which actor expectations converge. ${ }^{22}$ Ikenberry and Kupchan argue that socialization is not an isolated process, but is instead a process of learning that transmits and reinforces ideas and substantive beliefs that is complementary to the process of manipulating material incentives. Working with the idea of hegemonic power, the authors find that socialization occurs primarily after wars and other large crises, when turmoil and instability is high and thus domestic institutions are more receptive to the material and persuasive powers of a credible hegemon. One mechanism by which this happens is through external inducement: "the hegemon initially uses economic and military incentives to induce smaller states to change their policies...It is only after secondary states have adjusted their policies to accord with those of the hegemon that the normative principles underlying the hegemon's policies come to be embraced as rightful by the elites." ${ }^{23}$ Literature on the causal micro-processes of the socialization process have tended to concentrate on the power of persuasion, either through the mechanism of epistemic communities or through the persuasive power of strong states and dominant IOs. ${ }^{24}$ Johnston states that a

\footnotetext{
${ }^{20}$ Important examples here include: Wade Jacoby, The Enlargement of the European Union and NATO: Ordering from the Menu in Central Europe (NY: Cambridge University Press, 2004); Frank Schimmelfennig, "Strategic Action in a Community Environment: The Decision to Enlarge the European Union to the East," Comparative Political Studies, Vol. 36, No. 1-2 (2003), pp. 156-183, and; K.M. Fierke and Antje Wiener, "Constructing Institutional Interests: EU and NATO Enlargement," Journal of European Public Policy, Vol. 6, No. 5 (December 1999), pp. 721-742.

${ }^{21}$ Nicholas G. Onuf, “Constructivism: A User’s Manual,” in V. Kubalkova, N. Onuf, and P. Kowert (Eds.), International Relations in a Constructed World (Armonk, NY: M.E. Sharpe, 1998), pp. 58-78.

${ }^{22}$ F.V. Kratochwil and John G. Ruggie, "International Organization: A State of the Art on an Art of the State,” International Organization, Vol. 40 (1986), pp. 753-775.

${ }^{23}$ G. John Ikenberry and Charles A. Kupchan, "Socialization and Hegemonic Power," International Organization, Vol.44 (1990), pp. 283-315. Quote from P. 290-1.

${ }^{24}$ Prominent examples include: Martha Finnemore and Kathryn Sikkink, "International Norm Dynamics and Political Change,” International Organization, Vol. 52 (1998), pp. 887-917; M.E. Keck and Kathryn Sikkink,
} 
common implication found in political socialization literature pertaining to international relations is the "internalization of the values, roles, and understandings held by a group that constitutes the society of which the actor becomes a member. ${ }^{, 25}$ but that this implication suggests that the mechanism of social influence is as much a factor as persuasion. While persuasion "has to do with cognition and the active assessment of the content of a particular message," ${ }^{26}$ social influence has to do with the "class of micro-processes that elicit pro-norm behavior through the distribution of social rewards and punishments., ${ }^{27}$ Non-material rewards may entail psychological well-being, approval, status, and a sense of belonging, whereas social punishments might include shaming, shunning, exclusion, or “dissonance derived from actions inconsistent with role and identity." ${ }^{28}$ Johnston’s distinction between persuasion and social influence is helpful as the notion of rewards and punishments identifies a means by which actors within society (beyond national-level elites) may be influenced to change behavior, develop new norms, or achieve new goals. This line of reasoning also accounts for different degrees of socialization among different states. An IO can put similar pressure on a number of states, but the behavioral outcomes of those states are often varied - Johnston's argument suggests the non-material factors behind this variation.

Although the power of IOs to socialize and persuade has been well-theorized, less work has focused on the specific power of IOs to foster a political security community - one which is accompanied by a shared regional identity - in regions where none previously existed, or has been drastically altered due to violent conflict. Our research attempts to tie together theories of

Activists Beyond Borders: Advocacy Networks in International Politics (Ithaca, NY: Cornell University Press, 1998); see also the extensive literature by Peter Haas on epistemic communities.

${ }^{25}$ Alastair Iain Johnston, “Treating International Institutions as Social Environments," International Studies Quarterly, Vol. 45 (2001), pp. 487-515. Quote from p. 495.

${ }^{26}$ Ibid., p.496.

${ }^{27}$ Ibid., p.499.

${ }^{28}$ Ibid. 
security community and of the socialization power of IOs in order to assess the progress of the Western Balkan countries towards the development of a regional security community. We address the causal role of the EU and NATO as a heavy external influence on community development within the Western Balkan countries through non-material socialization.

\section{Theoretical Expectations and Empirical Indicators}

Based on existing literature, we can trace the potential development of security community in the Western Balkan region and outline the various kinds of empirical evidence that demonstrate the effects of mutual trust and collective identity. Adler and Barnett, for example, suggest that three tiers of community development highlight the factors leading to community development. The first tier, consisting of "precipitating conditions," includes those factors that might spark states to "begin to orient themselves in each other's direction and desire to coordinate their relations." ${ }^{29}$ Factors such as technological advances; demographic, economic and environmental changes; external threats; and changed ideas or perceptions about "social reality" can precipitate the beginnings of security cooperation.

The second tier reflects both structural and procedural factors - factors that are conducive to the development of a security community. In terms of structure, both power and knowledge are relevant. Power refers to the role of certain powerful actors in the development of security community, while knowledge refers to the various ideas, such as liberal democracy, civil society, rule of law, and human rights, that facilitate the creation of trust and a sense of community. Regarding process, members of a security community are expected to engage in increasing transactions of various kinds, quality, and quantity. International organizations also play a

\footnotetext{
${ }^{29}$ Adler and Barnett, “A Framework for the Study of Security Communities,” in Adler and Barnett, eds., Security Communities, pp. 37-38.
} 
significant role procedurally in that they enhance the creation of norms, allow members to monitor, and increase trust. International organizations are related to the third process factor social learning. Security community emerges following a process of teaching and learning, and international organizations play a significant role in that process. Ultimately, "by promoting the development of shared definitions of security, proper domestic and international action and regional boundaries, social learning encourages political actors to see each other as trustworthy. And it also leads people to identify with those who were once on the other side of cognitive divides. ${ }^{30}$

Finally, the third tier includes the "necessary conditions of dependable expectations of peaceful change.”31 These conditions involve mutual trust and collective identity, which are “reciprocal and reinforcing.”32 At this level, "states no longer rely on concrete international organizations to maintain trust, but do so through knowledge and beliefs about the other.”33

Based on these three tiers, Adler and Barnett suggest that security communities develop in three phases. The first, "nascent" phase exhibits all the characteristics present in tier one and some of those present at tier two. ${ }^{34}$ In the second, "ascendant” phase, security communities demonstrate tighter relations that are increasingly deeper over time. Tier two factors are entirely present and some tier three characteristics might be evident. ${ }^{35}$ Finally, in the "mature" phase, security communities are entirely developed and stabled.

\section{Research Hypothesis and Expected Behavior:}

Based on the theoretical understanding of security community, our hypothesis is:

\footnotetext{
${ }^{30}$ Ibid., p. 45.

${ }^{31}$ Ibid.

${ }^{32}$ Ibid.

${ }^{33}$ Ibid., p. 46.

${ }^{34}$ Ibid., pp. 50-53.

${ }^{35}$ Ibid., pp. 53-55.
} 
H1: When external third-parties, such as international organizations, engage and facilitate positively rewarding activities and internal interaction in post conflict societies, a security community, with corresponding feelings of trust and mutual responsiveness is most likely to develop.

To examine this hypothesis, it is necessary to consider the actions of external actors in the region. This entails an in depth analysis of two of the major IOs present in the region (the EU and NATO) and their interactions with the six countries of the Western Balkans. This includes looking at the various programs that these external organizations advance and the requirements that partnership with the IO mandates. To operationalize the independent variable we look for evidence of IO engagement in the region and IO facilitation of positively rewarding activities and internal interaction. Such evidence includes IO initiatives and programs that reward state behavior geared towards developing a regional security community, and/or that attach IO rewards to regional community development. For the dependent variable - the development of a security community, feelings of trust and mutual responsiveness - we expect to see heightened interactions and transaction flows along cultural, educational, economic and political channels; policy statements geared towards reconciliation in the region; and a rise in regional identification, measured by language that demonstrates these countries view each other as less threatening than they once did. Borrowing Ikenberry and Kupchan’s notion of socialization being complementary to the manipulation of material incentives, we borrow their causal chain of “acts before beliefs”, where external inducement leads to policy change, which then in turn slowly leads to norm change. ${ }^{36}$

Our methodological choices are driven by our research questions. Non-material factors, such as trust, sense of belonging, and feelings of reconciliation, are admittedly challenging for social scientific inquiry. Despite the challenges, however, analysis of these concepts and issues is

\footnotetext{
${ }^{36}$ Ikenberry and Kupchan, p. 291.
} 
critical for an understanding of how peace and stability can be fostered through the external encouragement of a joint regional identity and sense of community. Qualitative methods provide a measurement of the role and internalization of security community. A better understanding of how trust, belonging, and reconciliation emerge will help create a clearer image of how external actors may help to resolve and prevent conflict.

\section{Violent Conflict in the Western Balkans: A (Recent) Historical Perspective}

After the Cold War ended and communism collapsed, grievances began to surface in the Western Balkans region. The precipitation of Yugoslavia's dissolution ushered ultra-nationalist Slobodan Milosevic onto the political scene in Serbia, where he used nationalist ideology to assert Serbian domination over the Yugoslav Federation. One nationalist turn begat another as the Yugoslav Republics of Slovenia, ${ }^{37}$ Croatia and Macedonia declared their independence from the Federation in 1991. The following year, Bosnia-Herzegovina (BiH) also sought independence, but this step was met with Serbian resistance. ${ }^{38}$ The deadly Bosnian conflict continued until 1995. After three years of inadequate European and international response, the Dayton Peace Agreement (DPA) was enacted to preserve a US-enforced armistice. It is estimated that more than 100,000 people were killed, and over one million were displaced. Other Western Balkan states gave asylum to refugees. Though Croatia was among those, its role in instigating the Bosnian conflict remains controversial. ${ }^{39}$ Two ethnically based entities resulted from the

\footnotetext{
${ }^{37}$ While part of the Yugoslav Republic, Slovenia escaped many of the hardships of the Balkan conflicts, and is not considered part of the Western Balkans by international organizations. Albania, on the other hand, was not part of the Yugoslav Republic, but is a Western Balkan state.

${ }^{38}$ Mike Bowker, “The Wars in Yugoslavia: Russia and the International Community,” Europe-Asia Studies, Vol.50, No.7 (1998), pp. 1245-1261.

${ }^{39}$ LeMoyne 2001.
} 
Bosnian conflict - the Federation of Bosnia-Herzegovina (BiH) representing a union of Muslims and Croats and the Republic of Srpska, comprising the local Serbians. ${ }^{40}$

Kosovo also declared independence in 1991, but received limited recognition as a political entity. The international community felt that Kosovo deserved rights as an autonomous region of the Republic of Serbia, but viewed those rights as part of Kosovo's status as a federal entity within Serbia rather than an independent nation. Tensions surrounding Kosovo did not turn violent until 1998, when once again Milosevic mobilized Serbian nationalists. However, after the experience of $\mathrm{BiH}$, where international action was neither swift nor successful, NATO acted quickly by initiating an air campaign to quell the violence and turn Milosevic over to The Hague. ${ }^{41}$ Other states of the Western Balkans lent assistance; Macedonia and Albania served as NATO launching grounds with as many as 18,000 NATO troops stationed in Macedonia and as many as 8,000 in Albania. Croatia also supported the mission by opening its airspace and providing support personnel.

In 2003, the Commonwealth of Serbia and Montenegro was formed as a federal arrangement under an EU-brokered agreement. In 2006, however, a successful referendum on Montenegrin independence was confirmed with assistance from the EU. ${ }^{42}$ On May 31, 2006, Montenegro's referendum verified that $55.5 \%$ of the voting population had indeed voted for independence. The Montenegrin Parliament made a formal Declaration of Independence on June 3, 2006. ${ }^{43}$ The five permanent members of the UN Security Council gave preliminary unanimous recognition of the referendum result, indicating that widespread international recognition of

\footnotetext{
${ }^{40}$ Tom Gallagher, The Balkans in the New Millenium: In the Shadow of War and Peace (New York: Routledge, 2005), p.132.

${ }^{41}$ Ibid, pp. 37-39.

42 "Montenegrin Press Review," BBC Monitoring Europe - Political, Friday April 7, 2006.

${ }^{43}$ BBC News: "Montenegro declares independence" May 31, 2006

(http://news.bbc.co.uk/1/hi/world/europe/5043462.stm). Retrieved October 2006.
} 
independent Montenegro would be swift. ${ }^{44}$ On June 12, 2006, the EU decided to establish relations with Montenegro as a sovereign and independent state. All EU Member States recognized the independence of Montenegro and established diplomatic relations with it. ${ }^{45}$ The Serbian government had previously stated that it favored the status quo, but after the election results, made a public announcement that it would respect the outcome of the election and not interfere with Montenegrin sovereignty. ${ }^{46}$ This is remarkable given the recent history of violent upheavals. However, Montenegro’s successful partition has left Kosovo once again arguing for its own independent status.

Serbia has not been the only troubled area of the former Yugoslavia or the Western Balkans. In 2001, the Macedonian government and ethnic Albanians engaged in a number of deadly skirmishes for a period of six months. There were a number of riots and kidnappings, which resulted in as many as 100 deaths. ${ }^{47}$ Many of the issues surfaced due to the poor conditions of the ethnic Albanians, most of who had fled to Macedonia during the Bosnian and Kosovo conflicts. With the Bosnian conflict fresh in mind the international community was quick to respond. NATO was able to broker peace (with the support of neighboring Albania) and establish peacekeeping operations in the country. In April 2003, the European Union took over from NATO and began its first sole military mission. The EU's Operation Concordia is comprised of 380 soldiers from 27 member and applicant countries of the Union. ${ }^{48}$ By December

\footnotetext{
${ }^{44}$ BBC News: "Montenegro declares independence” May 31, 2006 (http://news.bbc.co.uk/1/hi/world/europe/5043462.stm). Retrieved October 2006.

${ }^{45}$ European Commission, “Montenegro 2006 Progress Report”. Brussels, November 8, 2006, SEC (2006) 1388.

${ }^{46}$ Serbian Government press release: "Serbia prepares measures defining its status as Serbia-Montenegro's successor” June 1, 2006 (http://www.srbija.sr.gov.yu/vesti/vest.php?id=23995\&q=Montenegro+independence). Retrieved December 2006.

${ }^{47}$ See the International Crisis Group's reports on the Macedonian crisis at http://www.crisisgroup.org/home/index.cfm?id=1244\&l=1.

48 "Macedonia Mission Shows Europe Doing its Bit for Security," April 16, 2003. Agence France Presse. and Saroska, Marina. December 11, 2001. "A the Civilian Casualties of the War," Reality Macedonia. Retrieved April 13, 2006.
} 
of 2003, Concordia was hailed as a success and officially ended. It was replaced by the EU mission Proxima, which sought to continue the peace by aiding in the policing of the county. ${ }^{49}$ There currently exist NATO and EU advisors in the state to monitor peace in Macedonia as well as in neighboring Kosovo. It is estimated that there are around 150 NATO troops still in Macedonia. ${ }^{50}$

While the recent history of the Western Balkans has been characterized by extremely violent conflict - which has included and enhanced the accompanying problems of corruption, instability, poverty and smuggling - it has also been the site of significant international involvement. Because of the events of the 1990s, the Western Balkans has received a great deal of international attention and involvement. This is significant in light of Ikenberry and Kupchan's hypothesis that socialization is more likely to occur after wars and political crises. Both NATO and the EU have used the lure of membership in their respective organizations to motivate positive changes in the region. All six Western Balkan countries have taken steps toward European and Atlantic integration by way of the accession processes for each IO. At present, Albania, Croatia, and Macedonia are members of NATO’s Membership Action Plan (MAP), which is designed to assist aspiring countries prepare to meet NATO's standards of membership. Once these countries have demonstrated their ability to meet the obligations of future membership, they must then be officially invited by NATO to begin accession talks. ${ }^{51}$ $\mathrm{BiH}$, Serbia, and Montenegro were invited to join NATO’s Partnership for Peace (PfP) program and the Euro-Atlantic Partnership Council at the 2006 NATO Riga Summit. This invitation

\footnotetext{
49 “Macedonian Parliament Approves Deploying of EU Police Mission,” December 12, 2003. Xinhua General News Service.

50 "Background Note: Macedonia," November 2005.” November 2005. US Department of State. Retrieved January 2006.

51 “NATO Issues: Enlargement”, at http://www.nato.int/issues/enlargement/index.html. Retrieved April 16, 2007.
} 
signals the beginning of bilateral relationships between each country and NATO designed to facilitate each country’s progress toward Euro-Atlantic integration. ${ }^{52}$

The progress of the Western Balkan countries toward EU membership is more varied. Only Croatia has official candidate status, with the expectation that the EU will likely admit Croatia after the next enlargement round in 2007. Macedonia has had a Stabilisation and Association Agreement (SAA) with the EU since 2004, and Albania began its SAA in 2006. SAAs include specific provisions for each country concerning future EU membership and policy harmonization. BiH has opened talks with the EU concerning a SAA, but the EU halted progress until BiH displayed results in reforming its police and cooperating with the UN International Criminal Tribunal for the Former Yugoslavia (ICTY). Serbia - which included Montenegro until 2006 - and the EU had begun discussion of opening talks on a SAA in October of 2005, but these talks were suspended in May 2006 because Serbia had not satisfactorily cooperated with the ICTY. ${ }^{53}$ Since May of 2006, the European Council has amended its negotiating directives for an SAA with Serbia because of the Montenegrin referendum. ${ }^{54}$ Croatia's separation from much of the regional violence, has allowed it to progress economically and politically faster than its neighbors towards EU membership. Serbia, due to its continually changing boarders and recent history of aggression is arguably the most difficult case for European integration.

\section{Security Community in the Western Balkans}

\section{International Organizations}

\footnotetext{
52 “NATO: Allied Joint Force Command Naples”, at http://www.jfcnaples.nato.int/releases/2007releases/PR_01_07.htm. Retrieved April 16, 2007.

53 "Commission Staff Working Document: Serbia 2006 Progress Report," Commission of the European Communities. Brussels (August 2006). SEC(2006) 1389.

http://ec.europa.eu/enlargement/pdf/key_documents/2006/Nov/sr_sec_1389_en.pdf. Retrieved April 23, $2007 .$.

54 “EurActiv.com: Enlargement and Neighbors Policy Section: EU-Western Balkans Relations," available at http://www.euractiv.com/en/enlargement/eu-western-balkans-relations/article-129607. Retrieved April 2007.
} 
An examination of the role external actors play in the promotion of security community relationships indicates organizations such as the EU and NATO have relied on conditionality as the main tool for the Balkan region. Attaching membership in elite international communities to adherence of Western security norms has shaped recent efforts in the Western Balkans to democratize and stabilize according to a Euro-Atlantic state socialization process. To the question of encouraging community-building, the EU in particular has relied on a method of “regionalization” in much of its dealings with the six states of the Western Balkans. ${ }^{55}$ This method relies on economic and political conditionality for the development of bilateral relations between the EU and each Balkan nation, rather than conditionality based on the area as a single community. The conditionality of membership initially focused on the socialization of individual countries into 'member-states', rather than socializing all six countries together into a shared identity within the region. As a result, some positive indicators of a regional security community exist within the Western Balkans, but mostly in an independent context. Each country has articulated some recognition of community-building, but appears do have done so only in response to IO prodding, and thus we see variation among the countries in their commitment to regional stability. EU programs, then NATO programs, follow below as examples of such conditionality.

EU policies towards the Balkans have "become embedded in the much broader process of EU enlargement that has followed the collapse of communism in Europe’s eastern half." ${ }^{56}$ In 1999, as part of the overarching Stability Pact program, the EU initiated the Stabilisation and Association Process (SAP) for five countries of South-East Europe as a means to offer the

\footnotetext{
${ }^{55}$ Kavalski (2003) offers a thorough discussion of this process: Emilian R. Kavalski, “The International Socialization of the Balkans,” The Review of International Affairs, Vol.2 (2003), pp. 71-88.

${ }^{56}$ Milada Anna Vachudova, "Strategies for European Integration and Democratization in the Balkans," Slovak Foreign Policy Affairs, Vol. 4 (2004), pp. 92-105, p. 92 in particular.
} 
possibility of future EU membership. EU membership is a powerful motivator for the Western Balkan countries to adopt relevant political and economic structural reforms in a timely manner. In essence, EU membership acts as a catalyst for structural reforms. While the general carrotand-stick metaphor of EU membership follows the same Copenhagen criteria as previous EU expansion and integration projects, the SAP is a specific attempt to address the conditions of South-East Europe through addressing the particular legacy of ethnic conflict in the region. This is done through a slower and more gradual timeline for institutional development than has been the expectation for previous enlargement candidates, and through emphasizing regional cooperation in recognition of the region's tumultuous history. ${ }^{57}$

Though not a contract for membership negotiations, the SAP creates a perspective on European integration by requiring the countries to mold their political, economic, and institutional development to the values and models underpinning the EU. The main objectives of the SAP are to contribute to the Stability Pact initiative - the first serious attempt by the international community to replace the previous, reactive crisis intervention policy in South-East Europe with a comprehensive, long-term conflict prevention strategy ${ }^{58}$ - to bring peace, stability, and economic development to South-East Europe, and to open a window on future EU membership. The key features of the SAP are:

Enhancement of the Regional Approach, which has until now provided the framework for the development of relations between the EU and Bosnia and Herzegovina, Croatia, the Federal Republic of Yugoslavia, the former Yugoslav Republic of Macedonia and Albania; a tailor-made, progressive approach that takes into account the individual situation of each country. Some countries can progress faster than others...Asymmetric trade liberalization; economic and financial assistance, budgetary assistance and balance of payment support; assistance for democratization and civil society; humanitarian aid for refugees,

\footnotetext{
${ }^{57}$ Europa website: http://www.delscg.cec.eu.int/en/eu_in_see/stabilisation.htm.

${ }^{58}$ Stability Pact website: http://www.stabilitypact.org. Retrieved March 27, 2006.
} 
returnees and other persons of concern; co-operation in justice and home affairs; development of a political dialogue. ${ }^{59}$

Since its initiation in 1999, the SAP's primary accomplishments have been in the form of the CARDS financial assistance program (Community Assistance for Reconstruction Development and Stabilisation): “CARDS represents a long-term assistance approach that targets through a single framework the needs of the country and reflects the objectives of the SAP. It focuses on reform support and institution-building, which are crucial for the successful implementation of the Stabilisation and Association Agreements (SAA)., ${ }^{60}$

For all countries, the stipulations attached to the financial assistance concern general capacity-building and economic development. More specifically, public administration reform, police reform, border management reform, improving the investment climate, democratic Stabilisation (including refugee return, civil society and media reforms), and structural reforms dealing with trade, infrastructure, environment, and education. Kosovo in particular is subject to a SAP tracking mechanism to ensure that the region is making productive efforts towards structural reforms. ${ }^{61}$

NATO’s presence in the Balkan region began when it deployed forces in $\mathrm{BiH}$ in what was the alliance's first successful peacekeeping operation in 1995, and then continued when it undertook a sustained air campaign in what was at the time a unified Serbia and Montenegro in 1999 during the Kosovo campaign. Today BiH, Serbia and Montenegro are all candidates for the Partnership for Peace (PfP) program - a NATO-led initiative to coalesce Europe in the wake of the Cold $\mathrm{War}^{62}$ - as part of aspirations to become NATO members themselves. This turn of

\footnotetext{
${ }^{59}$ Europa website: http://www.delscg.cec.eu.int/en/eu_in_see/stabilisation.htm. Retrieved March 27, 2006.

${ }^{60}$ Europa: Economic Reconstruction and Development in South East Europe. Http://www.seerecon.org/gen/eusee.htm. Retrieved March 27, 2006.

${ }^{61}$ Ibid.

${ }^{62}$ United States Joint Forces Command website: http://www.jfcom.mil/about/fact_pfp.htm. Retrieved March 27, 2006.
} 
events represents a significant change in the perceptions of a security community at both the international and regional levels: "The turnaround in relations between NATO and Serbia and Montenegro is probably the most spectacular security-related development to have taken place in the former Yugoslavia since the 1999 Kosovo conflict." ${ }^{, 63}$ A key component of the PfP program is the interoperability between aspirant countries and NATO forces to prepare their force structures and capabilities for future membership. ${ }^{64}$ The NATO-led Stabilisation Force (SFOR) did not leave BiH until December 2004, a development that indicated both the relative improvement in the region's security and the heightened presence of the EU's own peacekeeping forces. The EU forces focused on the more ground-level elements of security, whereas SFOR remained concerned with the larger framework of defense reform. ${ }^{65}$

Similar to the EU, the main incentives are the potential assistance afforded to them under the PfP program and the signaling to other countries that domestic stabilization efforts have reached a prominent developmental point. In this sense, PfP membership affords the two countries both material and social goods. Because of the peculiar nature of the region's recent history with NATO-led forces, arriving at a preliminary stage of NATO membership represents an important stage in the South-East Europe’s democratization.

Bjola suggests that NATO can impact the political stability of the Western Balkan region by planting "the institutional and normative seeds necessary for the incorporation [of the region] into the Western security community”, to help with the facilitation, support and enhancement of

\footnotetext{
${ }^{63}$ Robert Serry, “NATO’s Balkan Odyssey” NATO Review (2003). Downloaded from http://www.nato.int/docu/review/2003/issue4/english/art3.html. Quote from p.1.

${ }^{64}$ Ibid.

${ }^{65}$ NATO Briefing, "Bringing Peace and Stability to the Balkans,” (2005). Retrieved from NATO website: http://www.nato.int/docu/briefing/balkans/html_en/balkans10.html. Page 3.
} 
political reform in the direction of democratic regimes. ${ }^{66}$ The effect of NATO on a Western Balkan security community, in this argument, is indirect - NATO’s influence extends primarily to encouraging the domestic stability of democratic institutions. Nathan corroborates this notion, and asserts that domestic stability is a necessary condition for security community. If states are to rely on dependable peaceful expectations of one another, stability within states ought to be as important a benchmark as stability between states; otherwise the possibility of cross-border violence and unrest looms large. ${ }^{67}$

The formal basis for PfP is the 'Framework Document', which sets out specific undertakings for each candidate country. A partnership is formed between each country and NATO to encourage the country to implement a number of generalized political commitments and specific security agendas. The former includes the maintenance and preservation of the principles of international law, the UN Charter, the Universal Declaration of Human Rights, and various international border agreements, arms agreements, and dispute settlement mechanisms. The latter entails increasing transparency and institutionalization of national defense systems, establishing civilian control over armed forces, cooperation in seeking out war-criminals, and eventually, to develop the capacity for joint action with NATO in future peacekeeping and humanitarian operations. ${ }^{68}$ NATO has often proclaimed its dedication to advancement for the region. In 2003, NATO Secretary General Lord Robertson commented “... NATO is committed to helping achieve the goal of a more secure, a more prosperous and more integrated Western Balkans. We will stay for as long as we are needed. This is not simply a question of sending

\footnotetext{
${ }^{66}$ Corneliu Bjola, "NATO as a Factor of Security Community Building: Enlargement and Democratization in Central and Eastern Europe,” EAPC-NATO Individual Fellowship Final Report 1999-2000, Central European University. Downloaded from www.nato.int/acad/fellow/99-01/bjola.pdf. Quote from pp. 9-10.

${ }^{67}$ Laurie Nathan, "Domestic Instability and Security Communities," European Journal of International Relations, Vol.12, No.2 (2006), pp. 275-299.

${ }^{68}$ NATO website: The Partnership for Peace at http://www.nato.int/issues/pfp/index.html. Retrieved March 27, 2006.
} 
troops to ensure stability but of providing expert assistance, building true partnership and holding out the prospect of eventual Alliance membership.”69

Kydd examines the criteria behind the NATO enlargement rounds, and concludes that the degree of uncertainty surrounding a state's motivations is positively related to the price of membership: "If states are relatively certain about one another's preferences, there will be little reason to have a high entry price for an institution, because state motivations, benign or malign, will already be known.” ${ }^{70}$ In this sense, the price of membership represents the degree of socialization necessary to accommodate the new member.

An oversimplified generalization of the distinction between EU-led efforts and NATOled efforts in the region would be to characterize EU involvement as primarily economic and institutional and NATO’s as primarily security and defense. This polarization, however, does not capture the efforts of each international organization to deal with the symbiotic relationship of political and market structures. In Macedonia, for example, the EU began to take on a security role, as its operations during the 2001 crisis there were the first sole military operations for the Union. ${ }^{71}$ Although the nature of NATO's engagement has changed since SFOR, the alliance has retained military headquarters in $\mathrm{BiH}$ and has increased its influence in the region’s security development. This involvement extends to counter-terrorism efforts, apprehending war-crimes suspects, and civil-military reform. ${ }^{72}$

While it is clear that external third party actors are heavily involved in the Western Balkans, the effectiveness of international initiatives has been subject to debate. Anastasakis and Bojicic-Dzelilovic find that almost all international efforts have been orchestrated in direct

\footnotetext{
${ }^{69}$ NATO Speeches Lord Robertson 2003

${ }^{70}$ Andrew Kydd, “Trust Building, Trust Breaking: The Dilemma of NATO Enlargment,” International Organization, Vol. 55, No.4 (2001), pp. 801-828. Quote from p.803.

71 “Macedonia Mission Shows Europe Dong its Bit for Security,” April 2003.

72 Ibid, p.4.
} 
reaction to regional conflicts and thus organized as remedies to violent conflicts. The authors argue that this is problematic because it targets the alleviation of specific crises and limits the long-term developmental value of such initiatives. ${ }^{73}$

The international push toward regional cooperation leads some observers to question the motivations of external actors. Some research asserts that international organizations such as the EU and NATO intentionally maintain externally-led efforts in the Balkan region as a means of enhancing their own legitimacy. Borinski states that NATO is taking advantage of the 'window of opportunity’ in the Balkans to achieve a “double enlargement” - involving simultaneous geographical and mission profile enlargement as the linchpin of NATO policy - with the objective of achieving a political success story for the organization's own standing rather then based on strategy alone. ${ }^{74}$ Vachudova asserts a similar hypothesis for the EU - the EU's willingness to consider future expansion to such a troublesome region is in part explainable by the material benefits the EU could accrue: "only by stabilizing the Balkans can the EU hope to make its Common Foreign and Security Policy (CFSP) more credible and boost its clout as a geopolitical actor." 75 Ikenberry and Kupchan’s notion of socialization offers a bigger picture to this contention. A hegemon (which we interpret as a proxy for an IO) could not be expected to interfere with a secondary state unless there were material benefits to gain from interference. Socialization occurs independent of a hegemon's motives, and accompanies the material benefits as domestic actors eventually internalize a hegemon’s substantive beliefs along with any tangible gains they accrue.

\footnotetext{
73 Othan Anastasakis and Vesna Bojicic-Dzelilovic, “Balkan Regional Cooperation and European Integration,” The Hellenic Observatory: The European Institute, LSE (2002). Retrieved from http://www/lse.ac.uk/collections/hellenic/Observatory/pdf/brie.pdf. Page 26 in particular.

${ }^{74}$ Philip Borinski, "NATO Towards the Double Enlargement: The Case of the Balkans,” Revue d'intégration européene, Vol. 24 (2002), pp. 113-136. Pages 113 and 132 specifically.

${ }^{75}$ Vachudova, p.93.
} 
A final concern with international-led efforts is the lack of systematic evaluation of each program's effectiveness. "With the exception of the Stability Pact, there are no reports evaluating the progress of regional initiatives. Some critical assessments from secondary sources that have appeared, from time to time, reflect the realization that initiatives have not produced the anticipated results. ${ }^{76}$ Part of this difficulty may stem from the inadequate institutional resources at the local level to prepare truly representative progress reports. Not all efforts, however, have gone unmonitored. European Commission reports related to the SAA provide yearly updates on the general successes and failures within the South-East European region. Moreover, the 2005 Progress Report on Albania, BiH, Serbia and Montenegro, and Kosovo states that more constructive and productive political dialogue needs to be maintained between Kosovo and Serbia-Montenegro (previous to the Montenegro referendum) ${ }^{77}$ In essence, IOs utilize language concerning community-building, but so far lack the mechanisms to credibly monitor and enforce results.

\section{Regional Identity}

Although international organizations have attempted to foster a collective identity through their membership and participation requirements, the approach has remained predominantly bilateral. This suggests that the main source of commonality among the Western Balkans is the effort to become a European member-state. It is important to remember that the states of the area have recently thought of themselves as adversaries rather than as a regional block. It is reasonable to suppose that a certain amount of trust and shared identity must arise

\footnotetext{
${ }^{76}$ Anastasakis and Bojcic-Dzelilovic, 26.

77 European Commission. 9 November 2005. "Key Findings of the 2005 Progress Reports on Albania, Bosnia and Herzegovina, Serbia and Montenegro and Kosovo.” Europa Press Releases, Memo/05/410. Brussels:http://europa.eu.int/rapid/pressReleasesAction.do?reference=MEMO/05/410\&format=HTML\&aged=0\&la nguage $=$ EN\&guiLanguage $=$ en .
} 
organically and endogenously for a viable security community to take hold in such an area. The downside of socializing each country independently as a member-state within prominent IOs is that it does not appear to foster genuine community sentiment within the region. One example is the relatively quicker pace of Croatia's achievement of candidate status to the EU. Some even suggest that "attempts on the part of individual countries to accelerate the process of EU integration have resulted in weakened cooperation at the regional level.”78 In this context, membership carries sizeable rewards for the individual country, but potentially negative implications for neighborly relations.

The South-East Europe Barometer of 2006 indicates general indifference among the Western Balkan countries’ opinions of each other's EU accession possibilities. When a random sample of residents of each country were asked whether they approved, disapproved, or had no preference concerning the EU membership of the other Western Balkan countries, the vast majority indicated approval or no preference. While the lack of people indicating disapproval bears some optimism towards improvement in regional relations, it should be noted that in almost all cases more residents chose 'no preference' over 'approval' in their opinion concerning other countries. This lack of camaraderie is hardly prescient of a viable security community. Similarly, when asked whether neighboring countries posed a real threat to peace and security in society, respondents were more likely to answer 'something of a threat' or 'minor threat' than to choose 'no threat'. 79

Efforts such as the SAP and the PfP are almost entirely external efforts, with nearly no input from local actors in the Western Balkans. As a result, “the ability of most South-East

\footnotetext{
${ }^{78}$ East-West Parliamentary Practice Project (EWPPP), "Legislatures and Citizens: strengthening democratic institutions and civil society in the Western Balkans”: http://www.ewppp.org/programmes/western_balkans.php.

79 “South-East Europe Barometer: Public Opinion Compared in 7 Countries," Paul Lazarfeld Society \& Austrian Society for European Politics (2006), Studies in Public Policy Number 407. The study was completed before Montengrin independence and so the Western Balkans is disaggregated as five rather than six countries.
} 
European regional initiatives to reflect the local specificities and needs and not the priorities of external actors has been doubted. ${ }^{80}$ However, the EU is taking the approach that peace and stability and a quicker path to the EU can be achieved and must be accompanied with greater regional cooperation. To this end they have published a statement outlining this specific goal and the organization's dedication to fostering cooperative relations within the region. The Regional Cooperation in the Western Balkans: A Policy Priority for the European Union (2005) ${ }^{81}$ states that cooperation between the states of the region is not a luxury, but a requirement for greater European integration. "Regional cooperation is also a specific requirement under the stabilisation and association agreements, which are already in place in the Former Yugoslav Republic of Macedonia and Croatia... regional cooperation is therefore a corner stone of the EU's policy framework for the western Balkans...”82 This is notable as it differs from any previous relationships the EU has had with prospective candidate countries. Iindeed, even in the case of Cyprus, where existing political and ethnic divisions between Greek-Cypriots and TurkishCypriots complicated the accession process, the EU did not stipulate that the political division of the island be resolved before negotiations could begin. ${ }^{83}$

The imposition of European-level mandates and institutional prescriptions is seen by many as necessary for such a problematic and ethnically divided region, ${ }^{84}$ yet one potential

\footnotetext{
${ }^{80}$ Ibid.

${ }^{81}$ European Commission 2005, The Regional Cooperation in the Western Balkans: A Policy Priority for the European Union, available at http://ec.europa.eu/enlargement/pdf/nf5703249enc_web_en.pdf.

${ }^{82}$ Ibid.

${ }^{83}$ Although some observers would argue that this is much more to do with the EU's existing political alliances and diplomacies with Greece than it is to do with a lack of concern over a potential Cypriot security community. See Christopher Brewin, The European Union and Cyprus (Cambridgeshire, England: The Eothen Press, 2000), or Thomas Diez, ed., The European Union and the Cyprus Conflict (New York: Manchester University Press, 2002).

${ }^{84}$ Relevant works here include Emilian R. Kavlaski, “The EU in the Balkans: Promoting an Elite Security Community," World Affairs, Vol. 8 (2004), pp. 98-116; and Matthew Nimetz, "Southeastern Europe in the Age of Globalism,” Mediterranean Quarterly, Vol. 16 (2005), pp. 16-32.
} 
complication of such a strategy is that it neglects to foster trust and socialization among Balkan neighbors from the ground-level instead of from the top-down. ${ }^{85}$

While exogenously mandated, signs of regional (or sub-regional) cooperation do exist.

Nowhere is this more pronounced than in the creation of the Adriatic Group as formed under the Adriatic Charter. Initially established as a means by which to work together toward NATO membership, the countries of Macedonia, Croatia and Albania have formed a sub-regional alliance that allows them to work both independently and collectively toward meeting NATO requirements. This is significant, because it has led to elite discourse across the three states as well as a realization among the leaders that they share common concerns and goals. ${ }^{86}$

The codification of the Adriatic Group came with the signing of the Adriatic Charter on May 2, 2003 by the leaders of Albania, Croatia and Macedonia. The initiative lays out a commitment by the three countries to work individually and together to strengthen their reforms for the purpose of seeking NATO membership, with the hopes of a similar effect for EU accession. The Charter “reaffirms the parties’ shared political commitment to strengthen democratic institutions, civil society, rule of law, market economies, and NATO-compatible militaries; to fight corruption and crime; and to protect human rights and civil liberties for all individuals in Albania, Croatia, Macedonia and the other countries of southeast Europe." ${ }^{87}$ The goals of the group go far beyond simple security concerns, affecting many aspects of life in the sub-region. The Group has even begun joint missions, one notable example being a twelvemember team of physicians sent to Afghanistan in $2005 .^{88}$

\footnotetext{
${ }^{85}$ Discussions of this potential complication include M. Massari, "Do All Roads Lead to Brussels? Analysis of the Different Trajectories of Croatia, Serbia-Montenegro and Bosnia-Herzegovina," Cambridge Review of International Affairs, Vol. 18 (2005), pp. 259-273; G. Knaus and M. Cox, “The 'Helsinki’ Moment in Southeastern Europe,” Journal of Democracy, Vol. 16 (2005), pp. 39-53.

${ }^{86}$ Adriatic Charter 2005, available at http://www.state.gov/r/pa/prs/ps/2003/20153.htm.

${ }^{87}$ Ibid.

${ }^{88}$ Ibid.
} 
The endurance and apparent success of the sub-regional Adriatic Group has led to efforts to extend the cooperation to the entire region. In November 2005, the Adriatic group met once again to discuss their path(s) toward NATO membership. Representatives from $\mathrm{BiH}$, Serbia and NATO-member Bulgaria were also present indicating a remarkable feat given the recent discord among these states. ${ }^{89}$ The common goal of membership appears to be creating more amicable relations, though there is certainly a long way to go before regional cooperation becomes an internalized and fully realized goal.

With regard to our stated theoretical expectation, the first tier is not only present but appears to be so predominantly in response to IO encouragement. Transaction flows both among the Western Balkan countries and between the Western Balkans and the European level are also organized and supervised according to EU policy. Within the framework of the SAP, trade agreements operate on three levels: the bilateral level, which comprises autonomous trade relations between individual countries and the EU; the regional level, where more than 30 bilateral agreements would be translated into one large intra-regional trade agreement among the Balkans; and the multilateral level, which already has Albania, Croatia, and Macedonia as members in the WTO and which finds $\mathrm{BiH}$ as a prospective candidate. ${ }^{90}$ Serbia and Montenegro were considered to be on a "twin-track" approach towards a SAA before the Montenegrin referendum. Since Montenegro’s independence, the EU has stated their intention to renegotiate "Europe agreements" with both Serbia and Montenegro for the period prior to possible future accession. ${ }^{91}$ A primary goal of the EU is to open up the Balkan borders to create a free trade area so that goods are more easily passed between countries of the region as well as exported out of

\footnotetext{
89 “Balkan Defense Ministers Discuss NATO Ambitions,” November 15, 2005. AP.

90 European Commission, "External Trade Issues - Balkans,” Europa website: http://europa.eu.int/comm/trade/issues/bilateral/regions/balkans/index_en.htm.

91 European Commission on Enlargement: “EU-Serbia relations”. http://ec.europa.eu/enlargement/serbia/eu_serbia_and_montenegro_relations_en.htm. Retrieved December 2006.
} 
the region to the rest of Europe and the world. SAP participation has assured the Balkan countries of eventual free access to the markets of EU countries. Opening up their own borders is a step toward integration and creates a situation similar to what will exist when they ascend into the Union. However, poor roads, infrastructure and economic concerns have limited the progress of the free-trade zone. ${ }^{92}$

The second tier of theoretical expectations, involving not only the structural power of external actors and the processes of transactions and exchanges, but also the knowledge-based power of ideas, values, and norms inherent in developing a security community, is less visible. Evidence of peace and security stabilization independent of any IO could illustrate the shaping power of knowledge, however most elite discourse in the region concerning community-building appears to be in response to IO-level criteria. Other areas where one might expect to find transaction flows - migration, tourism, cultural, and educational exchanges - are not sufficiently developed enough to offer empirical evidence. One area of note, however, is that existing forms of cultural tourism remain organized through external actors. Much like trade and security policies, many attempts at promoting tourism or migration within the Western Balkan region lie with international organizations and external efforts. ${ }^{93}$ Croatia, for example, has tagged much of its economic hopes on attracting European tourism to its famous coastline, yet there seems little indication that they are simultaneously attempting to encourage their immediate neighbors to vacation on the Croatian shores. ${ }^{94}$

\footnotetext{
${ }^{92}$ European Commission 2005, p. 7.

${ }^{93}$ One example is the U.S. Agency for International Development (USAID), which has undertaken the beginnings of cultural tourism in Bosnia-Herzegovina, and which seeks to link tourist efforts to general improvements in business privatization and structural economic reforms in the country. According to Alvin Rosembaum, "Cultural Tourism in Bosnia \& Herzegovina: Preliminary Findings," (USAID: February 2006) BiH does not currently have any kind of state-level public sector tourism ministry or promotional agency (retrieved from http://www.usaidcca.ba/RosenbaumFeb06.pdf).

${ }^{94}$ The Croatian National Tourist Board website choice of languages and available packages illustrates this to some degree: http://www.croatia.hr/English/Home/Naslovna.aspx.
} 
Taken together, the Western Balkan region appears to be in the process of developing the second tier of theoretical expectations, albeit slowly, and not in an entirely linear fashion. This is not necessarily pessimistic for the eventual development of a security community, as Ikenberry and Kupchan indicate, if the countries are in process of internalizing IO norms to ultimately adopt them as their own. It remains to be seen, however, whether the current level of security community development in the region will ultimately prevent violent conflict within and among Western Balkan countries.

\section{Conclusions, Implications, and Suggestions for Future Research}

Judging from evidence to date, the ability of IOs to foster a security community within the Western Balkan appears mixed. The hypothesis, which asks whether a security community is most likely to develop in post-conflict societies when IOs engage and facilitate positively rewarding activities and internal interaction, cannot be conclusively supported at this juncture. It is reasonable to surmise that IOs could have the potential to reinforce and encourage the seeds of a regional security community that already exist, but cannot in and of themselves create a security community where no previous community exists or where it has been seriously damaged by violent conflict. The emphasis on membership within both the EU and NATO has motivated a series of actions towards structural reforms in each of the countries, but the socialization process has been geared primarily towards a shared identity of being 'European' rather than 'Balkan'. This does seem to be changing as the EU, at least, has developed a more local, regional approach by suggesting that "Regional cooperation in the western Balkans is...a catalyst for reconciliation, good-neighbourliness and good political relations." ${ }^{95}$ Nonetheless, the opinion polls from the

\footnotetext{
95 European Commission 2005, The Regional Cooperation in the Western Balkans: A Policy Priority for the European Union, available at http://ec.europa.eu/enlargement/pdf/nf5703249enc_web_en.pdf, p. 27.
} 
South-East Europe Barometer are especially telling on this point. The Western Balkan countries have been socialized to associate IO membership with modernization, but not yet to associate IO membership with regional trust. Moreover, local trust continues to be rather weak.

Ultimately, international efforts at promoting security in the Balkan region remain ad hoc arrangements with mixed results. ${ }^{96}$ The carrot-and-stick strategy of membership into elite international organizations holds promise as a general incentive for states to initiate reforms around European-prescribed norms, but lacks prescriptive elements that are truly attuned to assuaging the lack of trust and communication among the countries. Despite the lack of attention directed at promoting local security communities among the Balkan states themselves, general progress in political areas such as judicial and police reforms do demonstrate the potential that membership in international organizations holds for certain internal reforms. ${ }^{97}$

Based on this analysis of security community development in the Western Balkans, it seems evident that IOs are an important presence in the region. It is also clear, however, that a sense of community is largely emerging between Europe and the Western Balkan countries individually, rather than within and among each of the countries in the region. Moreover, the bilateral relationships that have emerged between Western Balkan countries and these important IOs have yet to reach the unmediated and multi-faceted level of interaction that is evident in more developed security communities. At the same time, the idea that communities are mental constructs that provide a referent for identification is somewhat illustrated by the idea of 'membership' in either the EU or NATO, given that each Western Balkan country appears ready to discuss difficult reforms as long as membership is held out as a future reward.

\footnotetext{
${ }^{96}$ Gallagher, p. 185.

${ }^{97}$ For details see the European Union's Justice and Home Affairs website, available at http://ec.europa.eu/justice_home/fsj/external/balkans/fsj_external_balkans_en.htm.
} 
Although an established security community that facilitates predictive, peaceful behavior is something that remains to be seen in the Western Balkan context, some initial indicators may be present given that deeper trade agreements are unfolding, an Adriatic Partnership is emerging, and a historically troubled entity like Serbia-Montenegro was able to successfully hold a referendum according to established liberal democratic principles. These facts demonstrate that a security community is possible, but remains rather weak and under-developed at this stage. In other words, the Western Balkans have accomplished the first tier of security community development, are beginning to demonstrate some characteristics inherent to the second tier, but are still far from internalizing the third tier. A significant amount of 'nascent' conditions exist precipitating factors such as external third parties, the promise of EU and NATO membership, heightened trade and economic possibilities, and the need for contained security - as do a number of 'ascendant' conditions, such as powerful IO actors and a process of social learning. But the region is still considerably far from approaching the 'mature' phase of a security community. The early phases of security community that are apparent are clearly supported by the involvement of external actors, as our hypothesis anticipated. It is no mistake that the Adriatic Group comprises the two countries in the region that have reached EU candidate status (Croatia and Macedonia). While Albania lags behind, it has still made substantial progress with the help of international organizations. It is also in these three countries where the chances for a permanent peace and the non-violent resolution of conflict seem the most plausible, though field research is necessary to confirm this.

These things taken together suggest that the sociological consequences of international involvement have been positive for initial developments. What is needed is continued engagement and further research in order to understand the deeper and more permanent 
consequences for community-building in the region. Specifically, we must focus our efforts now on more fully and deeply gauging the existence of trust, mutual responsiveness, and collective identity within and among these Western Balkan countries. Only then can we understand the extent to which these countries have moved beyond the consideration of violent resolution of conflict - and the extent to which external third parties, such as the EU and NATO, have and can enhance the development of security community in post-conflict zones. 